\title{
A new glassfrog (Centrolenidae) from the Chocó-Andean Río Manduriacu Reserve, Ecuador, endangered by mining
}

\author{
Juan M Guayasamin Corresp., 1,2 ， Diego F. Cisneros-Heredia ${ }^{3,4}$ ， José Vieira ${ }^{1,5}$ ， Sebastián Kohn ${ }^{6,7}$ ，Gabriela \\ Gavilanes ${ }^{1}$, Ryan L Lynch ${ }^{8}$, Paul S Hamilton ${ }^{9}$, Ross J Maynard ${ }^{9}$ \\ ${ }^{1}$ Laboratorio de Biología Evolutiva, Colegio de Ciencias Biológicas y Ambientales COCIBA, Instituto BIÓSFERA-USFQ, Campus Cumbayá, Universidad San \\ Francisco de Quito USFQ, Quito, Ecuador \\ 2 Centro de Investigación de la Biodiversidad y Cambio Climático, Ingeniería en Biodiversidad y Recursos Genéticos, Facultad de Ciencias del Medio \\ Ambiente, Universidad Tecnológica Indoamérica, Quito, Ecuador

We describe a new glassfrog from Río Manduriacu Reserve, Imbabura Province, on the Pacific slopes of the Ecuadorian Andes. The new species can be distinguished from most other glassfrogs by having numerous yellow spots on the dorsum and lacking membranes among fingers. Both morphological and molecular data support the placement of the species in the genus Nymphargus. We present a new mitochondrial phylogeny of Nymphargus and discuss the speciation patterns of this genus; most importantly, recent speciation events seem to result from the effect of the linearity of the Andes. Finally, although the new species occurs within a private reserve, it is seriously endangered by mining activities; thus, following IUCN criteria, we consider the new species as Critically Endangered.

\section{RESUMEN}

Se describe una nueva rana de cristal de la Reserva Río Manduriacu, provincia de Imbabura, en la vertiente pacífica de los Andes del Ecuador. La nueva especie se diferencia de sus congenéricos principalmente por tener un dorso con numerosos puntos amarillos y por carecer de membranas entre los dedos de la mano. Tanto los datos morfológicos como los moleculares apoyan la inclusión de la especie en el género Nymphargus. Se presenta una nueva filogenia mitocondrial de Nymphargus y discutimos los patrones de especiación de este género. El resultado biogeográfico más relevante es que la especiación reciente dentro del género parece ser el resultado de la linearidad de los Andes. Finalmente, a pesar de que la nueva especie se encuentra dentro de una reserva privada, está seriamente amenazada por actividades mineras, por lo que, siguiendo los criterios de la UICN, la consideramos como Críticamente Amenazada. 
2 A new glassfrog (Centrolenidae) from the Chocó-

3 Andean Río Manduriacu Reserve, Ecuador, 4 endangered by mining.

5

6

\section{7}

8

Juan M. Guayasamin ${ }^{1,2}$, Diego F. Cisneros-Heredia ${ }^{3,8}$, José Vieira ${ }^{1,4}$, Sebastián Kohn ${ }^{5,9}$, Gabriela Gavilanes ${ }^{1}$, Ryan L. Lynch ${ }^{6}$, Paul S. Hamilton ${ }^{7}$, Ross J. Maynard ${ }^{7}$.

${ }^{1}$ Universidad San Francisco de Quito USFQ, Laboratorio de Biología Evolutiva, Colegio de Ciencias Biológicas y Ambientales COCIBA, Instituto BIÓSFERA-USFQ, Campus Cumbayá, Quito, Ecuador. ${ }^{2}$ Centro de Investigación de la Biodiversidad y Cambio Climático (BioCamb), Ingeniería en Biodiversidad y Recursos Genéticos, Facultad de Ciencias del Medio Ambiente, Universidad Tecnológica Indoamérica, Quito, Ecuador.

${ }^{3}$ Universidad San Francisco de Quito USFQ, Colegio de Ciencias Biológicas y Ambientales COCIBA, Instituto de Zoología Terrestre y Museo de Zoología, Instituto de Geografía, Campus Cumbayá, Quito, Ecuador.

${ }^{4}$ Tropical Herping, Quito, Ecuador.

${ }^{5}$ Fundación Cóndor Andino, Quito, Ecuador.

${ }^{6}$ Third Millennium Alliance, California, USA.

${ }^{7}$ The Biodiversity Group, Tucson, Arizona, USA.

${ }^{8}$ División de Herpetología, Instituto Nacional de Biodiversidad INABIO, Quito, Ecuador.

${ }^{9}$ Fundación EcoMinga, Baños, Ecuador

Corresponding Author:

Juan M. Guayasamin

Universidad San Francisco de Quito USFQ, Laboratorio de Biología Evolutiva, Colegio de Ciencias Biológicas y Ambientales COCIBA, Instituto BIÓSFERA-USFQ, Campus Cumbayá, Quito, Ecuador. Email address: jmguayasamin@usfq.edu.ec 


\section{INTRODUCTION}

34 Glassfrogs represent one of the most charismatic Neotropical radiations (see Guayasamin et al.,

35 2009; Hutter et al., 2013; Castroviejo-Fisher et al., 2014). This clade contains more than 150

36 species, with an amazing variety of morphology (Cisneros-Heredia \& McDiarmid, 2007;

37 Guayasamin et al., 2009), behavior (Delia et al., 2017, 2018), and unresolved taxonomic

38 problems.

39 Within the tropical Andes, the most diverse glassfrog genus is Nymphargus (Cisneros-Heredia \& 40 McDiarmid, 2007, as modified by Guayasamin et al., 2009), a taxon previously defined as the 41 Cochranella ocellata Group (Ruiz-Carranza \& Lynch, 1991, 1995). Nymphargus is a 42 monophyletic taxon containing 36 species (Frost, 2018). This Andean genus is primarily

43 composed of species with restricted distributions and, therefore, it is not unusual to find new taxa 44 in previously unexplored areas (e.g., N. caucanus Rada, Ospina-Sarria, Guayasamin, 2017; N.

45 sucre Guayasamin, 2013; N. buenaventura Cisneros-Heredia \& Yánez-Muñoz, 2007).

46 Recent fieldwork at Río Manduriacu Reserve (RMR, hereafter), Imbabura Province, Ecuador,

47 has revealed a striking new Nymphargus that we describe below. The new species, and two other

48 critically endangered anurans, Nymphargus balionotus (Duellman, 1981) and Rhaebo olallai

49 (Hoogmoed, 1985) are threatened by illegal mining activities within the reserve (see Discussion;

50 Lynch et al., 2014).

51 Although our work presents several novel components (i.e., new phylogeny of Nymphargus,

52 discussion of biogeographic patterns), we would like to stress the discussion on the conservation

53 problems that the Chocó-Andean forests of Ecuador are currently facing. Ecuador is a

54 megadiverse country (Mittermeier et al., 1999), part of the most diverse hotspot on Earth (the

55 Tropical Andes; Myers et al., 2000), and the country with the highest amphibian species richness 
56 per unit of area of the world (600 species in an area of $\left.256,423 \mathrm{~km}^{2}\right)$. However, ecosystems are

57 under heavy pressure from agriculture, wood extraction, oil palm plantation, and, most recently,

58 mining (Roy et al., 2018; Lessmann et al., 2016). Our study, thus, is an attempt to draw attention

59 from the government, NGOs, local communities, scientists, and the general public towards the

60

61

62

63

64

65

66

67

conservations of the few Chocó-Andean forests still remaining in Ecuador. We also think that

taxonomists should play a more active role in conservation biology, mainly because the results of our work (i.e., new species with limited distributions) are powerful tools to justify habitat conservation, specially through partnerships with environmental NGOs.

\section{MATERIALS \& METHODS}

Ethics statement: Research was conducted under permits NoMAE-DNB-CM-2015-2017 and 018-2017-IC-FAU-DNB/MAE, issued by the Ministerio del Ambiente del Ecuador. The study was carried out in accordance with the guidelines for use of live amphibians and reptiles in field research (Beaupre et al. 2004), compiled by the American Society of Ichthyologists and Herpetologists (ASIH), the Herpetologists' League (HL) and the Society for the Study of Amphibians and Reptiles (SSAR).

Taxonomy and species concept: Glassfrog generic and family names follow the taxonomy proposed by Guayasamin et al. (2009). For recognizing species, we adhere to the General Species Concept (de Queiroz 2005, 2007). Under this concept, the only necessary property for an entity to be a recognized as a species is that it corresponds to a temporal segment of a metapopulation lineage evolving separately from other lineages (de Queiroz, 2005, 2007). 
79 Independent evolution generates traits that can be used to diagnose the species, such as

80 morphology, monophyly, vocalizations, among others.

81

82 The electronic version of this article in Portable Document Format (PDF) will represent a 83 published work according to the International Commission on Zoological Nomenclature (ICZN),

84 and hence the new names contained in the electronic version are effectively published under that

85 Code from the electronic edition alone. This published work, and the nomenclatural acts it

86 contains, have been registered in ZooBank, the online registration system for the ICZN. The

87 ZooBank LSIDs (Life Science Identifiers) can be resolved and the associated information viewed

88 through any standard web browser by appending the LSID to the prefix http://zoobank.org/. The

89 LSID for this publication is: urn:Isid:zoobank.org:pub:E5C0E7E4-9C69-4830-A514-

90 AD1F4B80311C. The online version of this work is archived and available from the following

91 digital repositories: PeerJ, PubMed Central and CLOCKSS.

92

93 Morphological data: Morphological characterization follows Cisneros-Heredia \& McDiarmid 94 (2007). Webbing nomenclature follows Savage \& Heyer (1967), as modified by Guayasamin et 95 al. (2006). We examined alcohol-preserved specimens mostly from the collection at the Instituto 96 de Ciencias Naturales of the Universidad Nacional de Colombia (ICN), Museo de Zoología of 97 the Universidad Tecnológica Indoamérica (MZUTI), Natural History Museum and Biodiversity 98 Research Center of the University of Kansas (KU), and Museo de Zoología of the Universidad 99 San Francisco de Quito (ZSFQ); all examined specimens are listed below. Morphological 100 measurements were taken with Mitutoyo ${ }^{\circledR}$ digital caliper to the nearest $0.1 \mathrm{~mm}$, as described by 101 Guayasamin \& Bonaccorso (2004) and Cisneros-Heredia \& McDiarmid (2007) except when 
102 noted, and are as follow: (1) snout-vent length (SVL); (2) tibia length; (3) foot length; (4) head

103 length; (5) head width; (6) interorbital distance; (7) upper eyelid width; (8) internarial distance;

104 (10) eye diameter; (11) tympanum diameter; (12) radioulna length; (13) hand length; (14) Finger

105 I length; (15) Finger II length = distance from outer margin of palmar tubercle to tip of Finger II;

106 (16) width of disc of Finger III. Sexual maturity was determined by the presence of vocal slits in

107 males and by the presence of eggs or convoluted oviducts in females. Color patterns are

108 described based on photographs of live specimens taken in the field. The adjective "enamelled"

109 is used to describe the shiny white coloration produced by accumulation of iridophores (Lynch \&

110 Duellman, 1973; Cisneros-Heredia \& McDiarmid, 2007). Examined material is listed in

111 Appendix 1.

112

113 Study site: The RMR $\left(0.31^{\circ} \mathrm{N}, 78.85^{\circ} \mathrm{W}, 1200-2000 \mathrm{~m}\right.$; Fig. 1$)$ is located at the juncture of the

114 Chocó and Tropical Andes bioregions, near the following Important Bird Areas and Key

115 Biodiversity Areas: Reserva Ecológica Cotacachi Cayapas (EC037), Intag-Toisán (EC038),

116 Bosque Protector Los Cedros (EC039), and Mashpi-Pachijal (EC108; Freile \& Santander, 2005).

117

118 Bioacoustics: Sound recordings were made with an Olympus LS-10 Linear PCM Field Recorder

119 and a Sennheiser K6-ME 66 unidirectional microphone. The calls were recorded in WAV format

120 with a sampling rate of $44.1 \mathrm{kHz} /$ second with 16 bits / sample. All calls are stored at the

121 Laboratorio de Biología Evolutiva at Universidad San Francisco de Quito (LBE). Measurements

122 of acoustic variables were obtained as described in Hutter et al. (2013). A call is defined as the

123 collection of acoustic signals emitted in sequence and produced in a single exhalation of air. A

124 note is a temporally distinct segment within a call; notes are separated by a silent interval. 
125 Pulsed notes are those having one or more clear amplitude peaks while tonal notes have

126 relatively constant amplitude throughout the call. A call series is defined as a sequence of calls

127 that are separated by a consistent time interval of background noise between calls (see Köhler et 128 al., 2017).

129

130 Fieldwork: Sampling at RMR was conducted during the following dates: 7-8 November 2012 131 (RL, SK), 13-15 May 2013, 21-22 February 2014 (Fernando Ayala, RL, SK, Santiago Ron), 813211 April 2018 (Jaime Culebras, Jorge Brito, SK), 17-30 October 2016 (PH, RJM, RL, and 3 133 assistants), 20-30 January 2018 (PH, RJM, Amanda Northrup, Nathalie Aall, Bill Langworthy, 134 and 2 assistants), 6-14 February 2018 (JV, PH, RJM, RL, SK, Jo Bowman, Bill Langworthy, and 1352 assistants). Visual encounter surveys (VES) were conducted along transects of various lengths 136 within primary forest, secondary and riparian forest, and along streams of various sizes. For 137 smaller streams that had thick vegetation and were too narrow to perform linear transects, we 138 performed general searches of the habitat. During the February 2018 trip (the only survey period 139 when the new species was abundant), surveys consisted of walks along different streams starting 140 at a $1900 \mathrm{~h}$ until $0200 \mathrm{~h}$ for nine nights.

142 Evolutionary relationships: We generated mitochondrial sequences (12S, 16S) for three 143 individuals (ZSFQ 462, 463, 466) of the new species and several other Nymphargus species

144 (Table S1). Extraction, amplification, and sequencing protocols are as described in Guayasamin 145 et al. (2008). The newly obtained sequences (Table S1) were compared with those of all other 146 available species of Nymphargus (see Fig. 2) and all other glassfrog genera, downloaded from 147 GenBank (https://www.ncbi.nlm.nih.gov/genbank/); sequence information and GenBank codes 
148 of the outgroups are listed in Guayasamin et al. (2008), Castroviejo-Fisher et al. (2014), and

149 Twomey, Delia \& Castroviejo-Fisher (2014). Sequences were aligned using MAFFT v.7

150 (Multiple Alignment Program for Amino Acid or Nucleotide Sequences:

151 http://mafft.cbrc.jp/alignment/software/), with the Q-INS-i strategy (Katoh \& Standley 2013).

152 MacClade 4.07 (Maddison \& Maddison, 2010) was used to visualize the alignment (no

153 modifications were necessary). Maximum likelihood was run in the IQ-TREE 1.5.5 software

154 (Nguyen et al., 2015). The best-fitting nucleotide substitution model was implemented using

155 ModelFinder within IQ-TREE (Kalyaanamoorthy et al., 2017), which groups partitions with the

156 same model and similar rates and simultaneously searches model and tree space; since only

157 mitochondrial sequences were analyzed, they were considered as a single gene (i.e., they evolve

158 as unit - maternal inheritance and no recombination). Node support was assessed via 1000 ultra-

159 fast bootstrap replicates, a method that shows less bias that other support estimates (Minh et al.,

160 2013). Ultra-fast bootstrapping also leads to straightforward interpretation of the support values

161 (e.g., support of $\geq 95 \%$ should be interpreted as significant; Minh et al., 2013).

162

163 RESULTS

164 Phylogenetic relationships of Nymphargus: Based on the Bayesian Information Criterion, the 165 best-fit model for our dataset was TIM2+F+R5. Rate parameters were estimated as follows: A166 C: 5.14658, A-G: 16.73402, A-T: 5.14658, C-G: 1.00000, C-T: 49.89941, G-T: 1.00000. Base

167 frequencies were: A: 0.341, C: 0.255, G: 0.186, T: 0.218. We generated 31 new sequences 168 (Table S1), including species that have never been part of centrolenid phylogenies.

169 The inferred phylogeny (Fig. 2) confirms the placement of the following species within the 170 genus Nymphargus (sensu Guayasamin et al. 2009): N. balionotus (Duellman, 1981), N.

171 cariticommatus (Wild, 1994), N. lasgralarias Hutter \& Guayasamin, 2012, N. spilotus (Ruiz- 
172 Carranza \& Lynch, 1997), and N. sucre Guayasamin, 2013. The new species, described below, is

173 also part of the genus Nymphargus. Relationships among Nymphargus species are similar to

174 those reported in previous studies (Guayasamin et al., 2008; Castroviejo-Fisher et al., 2014;

175 Twomey, Delia \& Castroviejo-Fisher, 2014), but some novel relationships are revealed because

176 of our increased taxon sampling (Fig. 2).

177

178 Species description

179

180

Nymphargus manduriacu new species

181

LSID urn:1sid:zoobank.org:pub:E5C0E7E4-9C69-4830-A514-AD1F4B80311C

182

183 Common names: English: Manduriacu glassfrog. Spanish: Rana de Cristal de Manduriacu.

184

185

Holotype: ZSFQ 0466 (Fig. 3), adult male from Reserva Río Manduriacu $\left(0.310755^{\circ} \mathrm{N}\right.$,

$\left.78.8569^{\circ} \mathrm{W} ; 1215 \mathrm{~m}\right)$, Provincia de Imbabura, República del Ecuador, collected by JV and RJM

187

on February $7^{\text {th }}, 2018$.

188

189

190

Paratypes: ZSFQ 0465, adult male, with same data as holotype. ZSFQ 0462, adult female, and ZSFQ 0463 (Fig. 3), adult male, with same data as holotype, but collected at a different stream $\left(0.310818^{\circ} \mathrm{N}, 78.857^{\circ} \mathrm{W} ; 1230 \mathrm{~m}\right)$ on February $6^{\text {th }}, 2018$.

192

193

Referred material: ZSFQ 0464 (Fig. 4), metamorph, with same data as holotype. 
195 Generic placement: The new species is placed in the genus Nymphargus Cisneros-Heredia \&

196 McDiarmid 2007, as modified by Guayasamin et al. (2009), based on morphological and genetic

197 data. All species in Nymphargus share an absence of webbing among Fingers I-III and absence

198 or reduced webbing between Fingers III and IV; additionally, males lack humeral spines (except

199 N. grandisonae; $N$. armatus and some populations of $N$. griffithsi have an enlarged ventral crest

200 on their humeri that can resemble a humeral spine). Nymphargus manduriacu sp. nov. presents

201 all the aforementioned traits and its placement within Nymphargus is unambiguous. Phylogenetic

202 analyses of mitochondrial genes also place $N$. manduriacu sp. nov. in the genus Nymphargus

203 (Fig. 2).

204

205 Diagnosis: Nymphargus manduriacu sp. nov. is distinguished from most glassfrogs by lacking

206 webbing between inner fingers and having, in life, a grayish green dorsum with numerous yellow

207 spots, which sometimes are surrounded by an ill-defined black ring (i.e., false ocelli). On the

208 Pacific slopes of the Ecuadorian and Colombian Andes, there are very few species that share the

209 two aforementioned traits with $N$. manduriacu sp. nov.; these species are: $N$. buenaventura, $N$.

210 ignotus, $N$. spilotus, and N. luminosus. Differences among these species are summarized in Table

2111 and Figures 5 and 6. The sister species of N. manduriacu sp. nov. is N. balionotus, which is

212 easily differentiated by its unique dorsal color pattern, a green dorsum with several black and

213 occasionally yellow to cinnamon blotches (Duellman, 1981; Arteaga et al., 2013). Also, the

214 uncorrected $p$ genetic distance between $N$. manduriacu sp. nov. and N. balionotus is $6.4-6.7 \%$

215 for the $12 \mathrm{~S}$ and $16 \mathrm{~S}$ concatenated matrix.

216 
217 Definition: The new species is distinguished from all other Centrolenidae by the following 218 combination of characters: (1) dentigerous process of vomer low or absent, without vomerine 219 teeth; (2) snout truncate in dorsal and truncate to slight rounded in lateral view; (3) tympanic 220 annulus barely evident, lower $3 / 4$ visible, tympanic membrane colored as dorsal skin, 221 supratympanic fold present; (4) dorsal skin shagreen, with microspicules in adult males; (5) 222 ventral skin granular, subcloacal area with two large subcloacal warts; (6) parietal peritoneum 223 white, iridophores covering $1 / 3$ to $1 / 2$ parietal peritoneum (conditions P2 or P3); pericardium 224 white (i.e., covered by iridophores), all other visceral peritonea clear (condition V1); (7) liver 225 lobed and hepatic peritoneum clear (lacking iridophore layer, condition H0); (8) adult males 226 without projecting humeral spine; (9) webbing between fingers I, II and III absent, basal between 227 fingers III and IV; (10) toe webbing basal between toes I and II, III $1^{1 / 2}-\left(2^{1 / 2}-3^{-}\right)$III $\left(1^{1 / 3}-1^{1 / 2}\right)-(3-$ 228 $\left.3^{-}\right)$IV $\left(3-3^{-}\right)-\left(1^{1 / 2}-2^{-}\right) \mathrm{V}$; (11) lacking dermal ornamentations in the form of tubercles, folds, or

229

230 231 232 233 234 235 236 237 238 239 fringes on hands, arms, feet, or legs; (12) nuptial excrescences Type I and VI; concealed prepollex; (13) Finger I slightly longer than Finger II; (14) diameter of eye larger than width of disc on Finger III; (15) color in life, grayish green to olive green with yellow spots, which, sometimes, are surrounded an ill-defined black ring (i.e., false ocelli); bones green; (16) color in preservative, lavender dorsum with cream spots; (17) iris coloration in life: light grey with thin grey reticulations and pale yellow hue around pupil; (18) melanophores present and abundant along Fingers III and IV, less dense on Finger II, and rarely present on Finger I, present and abundant along Toes IV and V, less dense on Toe III, only at the base of Toes I and II; (19) males call from upper side of leaves; advertisement call is a high-pitched "chirp", with a single, pulsed note with a duration of $0.093-0.118 \mathrm{~s}(\overline{\mathrm{x}}=0.10 \pm 0.007 ; n=10)$ and a dominant frequency at $4052-4447 \mathrm{~Hz}(\overline{\mathrm{x}}=4267.7 \pm 118.3)$; (20) fighting behavior unknown; (21) egg 
240 masses deposited on upper side of leaves, clutch size 15-32 $(n=4)$; males do not attend or get in 241 contact with clutches; (22) tadpoles undescribed; (23) snout-vent length (SVL) in adult males

$242 \quad 24.0-25.7 \mathrm{~mm}(n=3)$, and in an adult female $28.8 \mathrm{~mm}$.

243

244 Description of holotype: Adult male (ZSFQ-0466; Figs. 3-7). Head wider than long (head

245 length $90 \%$ of head width); snout truncate in dorsal view and slightly rounded in lateral profile;

246 canthus rostralis indistinct, slightly concave; loreal region concave; lips not flared; nostrils

247 protuberant, closer to tip of snout than to eye, directed frontolaterally; internarial area barely

248 depressed. Eyes large, directed anterolaterally at an angle $\sim 45^{\circ}$; transverse diameter of disc of

249 Finger III 53\% eye diameter. Supratympanic fold low, obscuring upper edge of tympanic

250 annulus; tympanic annulus small and almost indistinct, oriented mostly vertically; tympanic

251 membrane colored as surrounding skin. Dentigerous process of vomer absent; choanae rounded;

252 tongue ovoid and unnotched, with ventral posterior fourth not attached to mouth floor; vocal slits 253 extending posterolaterally from about the lateral margin of tongue (at about half the length of 254 tongue) to angle of jaws.

255

256 Humeral spine absent. Hand and ulnar folds absent; relative lengths of fingers: III $>$ IV $>$ II $>$ I;

257 webbing absent between Fingers I-III, basal between Fingers III and IV, webbing formula III $2582^{3 / 4}-2^{3 / 4} \mathrm{IV}$; discs expanded, nearly elliptical; disc pads with triangular shape; subarticular 259 tubercles small, round, simple; supernumerary tubercles numerous, fleshy, giving the palm a 260 warty texture; palmar tubercle elliptical, simple; nuptial pad Type I present but faint, extending 261 from ventrolateral base to dorsal surface of Finger I, covering the proximal half of Finger I. 262 
263 Length of tibia 59\% SVL; tarsal folds absent; two-thirds webbed foot; toe webbing basal

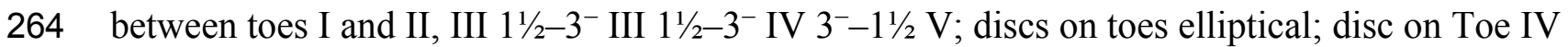

265 narrower that disc on Finger III; disc pads triangular; inner metatarsal tubercle large, ovoid; outer

266 metatarsal not evident; subarticular tubercles small, round; supernumerary tubercles absent. Skin

267 on dorsal surfaces of head, body, and lateral surface of head and flanks shagreen with numerous

268 minute spinules; throat smooth; belly and lower flanks granular; cloacal opening directed

269 posteriorly at upper level of thighs; cloacal ornamentation absent except for pair of enlarged

270 subcloacal tubercles.

271

272 Color in life: Grayish green to olive green dorsum with yellow spots. Melanophores

273 concentrated around yellow spots, sometimes looking like false ocelli. Upper lip unpigmented.

274 Inner fingers and toes yellowish. Anterior half of ventral parietal peritoneum white, posterior

275 portion translucent. Color of bones green. Iris light grey with thin, dark grey reticulations and 276 pale yellow hue around pupil (Figs. 3, 5).

277

278 Color in ethanol: Dorsal surfaces gray lavender with small white spots. Parietal peritoneum

279 white, iridophores covering $1 / 3$ to $1 / 2$ parietal peritoneum. Heart covered by white pericardium;

280 all other visceral peritonea unpigmented.

281

282 Variation: The only known female is larger than males and lacks microspicules (Fig. 1). Male

283 holotype was slightly greener than female. Metamorph was uniformly green showing faint light

284 spots. Meristic variation is reported in Table 2. 
286 Natural history: Although RMR has been visited numerous times during the past years (see 287 Methods), the new species was only regularly detected during February 2018. This was during 288 the wet season, with the site experiencing particularly heavy rains on a daily basis during this 289 time frame. During all previous surveys, only a single individual was observed along a transect 290 in mature secondary forest $\left(0.3144^{\circ} \mathrm{N}, 78.855^{\circ} \mathrm{W} ; 1238 \mathrm{~m} ; 22\right.$ October 2016 at $\left.2036 \mathrm{~h}\right)$. The 291 point where the individual was found was along a narrow, sloping ridge, with the Manduriacu 292 River ca. $20 \mathrm{~m}$ east, and a smaller stream (ca. 3-4 m wide) about $15 \mathrm{~m}$ west; the individual, 293 uncollected, was perched on a leaf with a perch-height of $350 \mathrm{~cm}$ when found.

294 In February 2018, even though sampling targeted numerous large rivers (ca. 4-7 m wide) and 295 smaller streams (ca. 0.5-2 m wide), all individuals of the new species were found in only two 296 places. The first location is a narrow stream (ca. $0.75 \mathrm{~m}$ wide, $0.310818^{\circ} \mathrm{N}, 78.857^{\circ} \mathrm{W} ; 1230 \mathrm{~m}$ ) 297 with dense vegetation, where on 6 February 2018 at 2033 h, a male (ZSFQ-0463) was calling 298 and perched on a leaf above the water $280 \mathrm{~cm}$ high, and a female (ZSFQ-0462) on a leaf below 299 the male, with a perch height of $170 \mathrm{~cm}$. Conditions were wet, with light rain during the time of 300 capture. The following night, three additional individuals were collected along the same stream. 301 The first was an adult male (ZSFQ-0465) collected at $1930 \mathrm{~h}$, found moving on a leaf $220 \mathrm{~cm}$ 302 above the ground, and located $5 \mathrm{~m}$ from the stream (i.e. not directly above water). The second 303 individual was a metamorph (ZSFQ-0464; $16.4 \mathrm{~mm} \mathrm{SVL)} \mathrm{collected} \mathrm{at} 2000 \mathrm{~h}$, perched on a leaf $304100 \mathrm{~cm}$ directly above the stream. The third specimen was a male (ZSFQ-0466) collected at 2200 $305 \mathrm{~h}$, perched on a leaf $400 \mathrm{~cm}$ directly above water. This male was $15-30 \mathrm{~cm}$ from four egg 306 clutches; these clutches, placed on the upper surfaces of leaves (Fig. 4), contained 26-32 307 embryos $(\overline{\mathrm{x}}=25.75 \pm 7.5883)$. Finally, an uncollected adult individual was found on 12 February 3082018 at $2311 \mathrm{~h}$ along a slightly larger stream (2-3 m wide) immediately adjacent to camp on the 
309 south side $\left(0.3104^{\circ} \mathrm{N}, 78.858^{\circ} \mathrm{W} ; 1224 \mathrm{~m}\right)$. This uncollected individual was perched in

310 herbaceous vegetation in an area where a large treefall was lying across the stream; the

311 individual was found $0.5 \mathrm{~m}$ from the stream, with a perch high of $65 \mathrm{~cm}$.

312

313 Call (Fig. 7): The following description is based on the recording of two males (ZSFQ 0465-

314 0466) obtained by JV on 05 February 2018 at the type locality. Each call is a high-pitched

315 "chirp" that consists of a single note and has a duration of $0.093-0.118 \mathrm{~s}(\overline{\mathrm{x}}=0.10 \pm 0.007 ; n=$ 316 10). Notes are pulsed ( $8-12$ pulses per note; $\bar{x}=10.33 \pm 1.366)$. In each call, there is a very

317 slight increase in the dominant frequency with time; the dominant frequency is at $4052-4447 \mathrm{~Hz}$ $318(\bar{x}=4267.7 \pm 118.3)$. Time between calls is 3.9-8.6 s $(\bar{x}=5.72 \pm 1.82)$. Among closely related 319 species to the new taxon (Fig. 2), only the call of $N$. grandisonae is described (Hutter et al. 320 2013). The call of $N$. manduriacu sp. nov. is differentiated mainly by having a higher dominant 321 frequency (4052-4447 Hz in N. manduriacu sp. nov., 3100-4048 Hz in N. grandisonae). 322

323 Evolutionary relationships of the new species: Given the gene and taxon sampling of our 324 study, Nymphargus manduriacu sp. nov. is sister to N. balionotus. The latter taxon was 325 considered to be as incertae sedis within the subfamily Centroleninae (Guayasamin et al. 2009).

326 Here we formally place Centrolenella balionota Duellman 1981 in the genus Nymphargus sensu 327 Guayasamin et al. 2009. Nymphargus manduriacu sp. nov. and N. balionotus are endemic to the 328 Pacific slopes of the northern Andes, and are found syntopically at RMR. 329

330 Distribution: Nymphargus manduriacu is only known from a few nearby streams within the Río 331 Manduriacu Reserve $\left(0.31^{\circ} \mathrm{N}, 78.85^{\circ} \mathrm{W}\right)$, Imbabura province, on the Pacific slopes of the Andes 
332 of Ecuador (Fig. 1). Based on these limited records, the species occupies a narrow elevational 333 range of $1215-1242 \mathrm{~m}$.

334

335 Conservation status: We recommend that Nymphargus manduriacu should be considered as 336 Critically Endangered, following IUCN (2001) criteria B2a (known to exist from a single

337 locality) and B2biii (continuing decline, observed, inferred or projected, in area, extent and/or 338 quality of habitat). The main threats for the species are habitat destruction and contamination 339 associated with cattle ranching, agriculture and, most seriously, mining activities (see

340 Discussion; Fig. 8). Although RMR is still poorly surveyed, northwestern Ecuador has been the 341 target of intense herpetological research (e.g., Lynch \& Duellman, 1973, 1997; Arteaga,

342 Bustamente \& Guayasamin, 2013; Arteaga et al., 2016), including areas nearby RMR (i.e.,

343 Reserva Los Cedros; Hutter \& Guayasamin, 2015); thus, the restricted distribution of the new

344 species is, most likely, real.

345

346 Etymology: The specific epithet "manduriacu" is a noun in apposition and refers to the type

347 locality of the species, Río Manduriacu Reserve, a conservation area managed by Fundación

348 EcoMinga (https://ecomingafoundation.wordpress.com/).

\section{DISCUSSION}

Biogeographic patterns within Nymphargus: The phylogeny we present (Figure 2) reveals a

352 number of biogeographic patterns that are worth highlighting. Given the current taxon sampling

353 (60\% of the described diversity of the genus), all sister species within Nymphargus are

354 geographic neighbors, including some sister taxa that, in some areas, are sympatric (e.g. $N$. 
355

356

357

358

359

360

361

362

363

364

365

366

367

368

369

370

371

372

373

374

375

376

377

manduriacu/N. balionotus, N. griffithsi/N. lasgralarias). On the Amazonian slope of the Andes, most sister species have allopatric distributions: $N$. aff. chancas/N. mariae, $N$. cariticommatus $/ N$.

sucre, $N$. cochranae/N. sp, N. siren/N. sp, N. pluvialis/N. posadae. The only two sampled

Nymphargus species distributed on the eastern slope of the Cordillera Central of Colombia $(N$. spilotus/N. rosadus) are also sister species. These biogeographic patterns are congruent with the

hypothesis that recent speciation in Nymphargus is mediated by the linearity of the Andes, which results in elongate geographical ranges and reduces potential contact and gene flow among parapatric populations (Remsen, 1984; Graves, 1988). It is also possible that dry river-valleys play a role as barriers (see Krabbe, 2008; Guayasamin et al., 2010; Arteaga et al., 2016; PrietoTorres et al., 2018; Winger \& Bates, 2015). Examples of dry Andean river valleys in Ecuador include the Mira, Guayllabamba, Jubones, Girón, and Paute. To date, however, there are no explicit studies designed to test the effect of the mentioned valleys on diversification processes.

Biodiversity value of Río Manduriacu Reserve: In Ecuador, RMR is a very atypical site for vertebrate diversity. It is the only known place that houses an extant reproducing population of the long lost and presumed-extinct Tandayapa Andean Toad (Rhaebo olallai; Lynch et al., 2014), and the Mindo Cochran frog (Nymphargus balionotus; R. Maynard, personal observation, 2016-2018). Both species had not been seen in the country for over three decades prior to their rediscovery at RMR. Additionally, there is a large number of other threatened amphibians, including the critically endangered Centrolene ballux and the endangered Pristimantis crenunguis, $P$. pteridophilus, and $P$. scolodiscus, as well as several undescribed anurans (e.g., Noblella sp, Pristimantis spp). The reserve also serves as a stronghold for other Critically Endangered animals, such as the brown-headed Spider Monkey (Ateles fusciceps fusciceps), 
378 included on the list of the 25 most endangered primates in the world (Schwitzer et al. 2017).

379 Other mammals recorded at RMR include the Spectacled Bear (Tremarctos ornatus), Pacarana

380 (Dinomys branickii), and Oncilla (Leopardus tigrinus), all classified as Vulnerable (IUCN VU)

381 (S. Kohn, personal observation, 2015-2018). Also notable is the presence of jaguars (Panthera

382 onca; S. Kohn, personal observation, 2016), as their populations along the western slopes of the

383 Andes are considered Critically Endangered, despite having a global status of Near Threatened

384 (Espinoza et al. 2011).

385

386 Threats to the Río Manduriacu Reserve

387 Mining: Immediate threats to the forests at RMR make the conservation of this newly described 388 species, and the biodiversity in the area, a difficult challenge. The primary threat comes from 389 mining concessions (Fig. 8) given by the government to Cerro Quebrado, a subsidiary to the 390 Australian BHP Hillinton, the world's largest mining company. Ecuador's legislation requires 391 that any mining operation must consult with local communities and landowners prior to any

392 mining activity (Article 398, Constitución del Ecuador, 2008). Despite the fact that Cerro

393 Quebrado did not consult the local population or local landowners, the Ecuadorian government 394 granted the company a concession to extract gold and copper through an open pit mine (see 395 mining cadaster: http://geo.controlminero.gob.ec:1026/geo visor/). Thus, with this

396 documentation in hand, it is clear that the mining concession in RMR and nearby areas are void 397 and that mining activities should be prohibited until Cerro Quebrado and the Ecuadorian 398 government abide by the Ecuadorian constitution.

399 Logging: Illegal and uncontrolled logging also pose a grave threat. Local communities have 400 relied historically on logging as one of their main sources of income. Nonetheless, this logging is 
401 mostly illegal (e.g., without government permits or using a permit for one area to extract wood

402 from a different area) and remains poorly regulated. As a result, forest cover in the area

403 surrounding RMR has been reduced drastically in the last two decades

404 (http://mapainteractivo.ambiente.gob.ec/portal/). This problem is exacerbated by the generalized

405 lack of legal land ownership titles.

406

407 Conservation actions: Numerous local landowners have protected the forest of RMR for several

408 decades. In 2010 several tracts of forest were incorporated into the Socio Bosque program, a

409 conservation initiative by the Ecuadorian government (http://sociobosque.ambiente.gob.ec/).

410 Through Socio Bosque, landowners and communities that are willing to conserve their forests

411 get financial incentives if they maintain the original forest cover. Starting in 2015 Fundación

412 EcoMinga signed an agreement with the owners of several lots to control, protect and manage

413 the reserve. Through this agreement all funds from Socio Bosque are directed to fund salaries of

414 park rangers and reserve managers. IUCN Netherlands has supported EcoMinga in purchasing

415 new plots in order to expand the reserve. With this new purchase the land belonging to RMR has

416 grown to almost 600 ha, while the plots affiliated to Socio Bosque, but outside the limits of the

417 reserve, cover an additional 350 ha. EcoMinga's medium and long term goal is to purchase

418 nearby land that is not under any conservation program.

419 In early 2017, EcoMinga began a community project to promote sustainable alternatives (e.g.

420 ecotourism, revenues from academic projects, sustainable agriculture, vanilla farming) to wood

421 extraction (training locals as guides, mainly for birdwatching tourism). The aim is to generate a

422 model for community work that is appropriate for the country and that can later be replicated in

423 other reserves. This program has faced difficulties since recently local community members were 
424 hired by Cerro Quebrado to illegally enter into RMR. This has created constant tension within 425 the communities and with stakeholders.

426

427

428

429

430

431

432

433

434

435

436

437

438

439

440

441

442

443

444

445

446

447

\section{CONCLUSIONS}

We provide morphological, genetic, and acoustic evidence that support the validity of a new species, Nymphargus manduriacu. Also, we infer a new mitochondrial phylogeny of the genus Nymphargus that allows us to reveal speciation patterns in this taxon, mainly that recent speciation events in this genus seem to be heavily influenced by the linearity of the Andes and dry river-valleys that are run transversal to this mountain range. Finally, the new species is considered as Critically Endangered because of its restricted distribution, habitat destruction and contamination associated with cattle ranching, agriculture and, most seriously, mining activities. At Río Manduriacu Reserve, mining has become one the most dangerous threats to biodiversity, specially to species with very restricted distributions.

\section{ACKNOWLEDGEMENTS}

The article benefited from reviews by two anonymous reviewers, and comments from Elisa Bonaccorso and Mario H. Yánez-Muñoz. The Biodiversity Group is grateful to Nathalie Aall, Jo Bowman, Bill Langworthy, Paul Maier, José María Loaiza, Amanda Northrup, Kristiina Ovaska, and Scott Trageser for assistance in the field. For access to collection specimens, we thank the Natural History Museum and Biodiversity Research Center of University of Kansas, Instituto de Ciencias Naturales of the Universidad Nacional de Colombia, and the Museo de Zoología of the Universidad Tecnológica Indoamérica. Sebastián Montilla and Carolina Reyes-Puig provided valuable assistance when we examined specimens at ICN and the ZSFQ, respectively. Sequences 
448 and photos of N. spilotus (JD 060) and Nymphargus sp. (LSB 210) were graciously provided by

449 Marco Rada and Jesse Delia. We also thank Juan Carlos Sánchez for providing the photo of $N$.

450 buenaventura.

451

452

\section{REFERENCES}

453

454

455

456

457

458

459

460

461

462

463

464

465

466

467

468

469

470

471

472

473

474

475

476

Arteaga-Navarro, A.F., Bustamante, M.R., Guayasamin, J.M. (2013) The Amphibians and

Reptiles of Mindo. Life in the Cloudforest. Serie de Publicaciones Científicas, Universidad Tecnológica Indoamérica. Publicación no. 1, pp. 257.

Arteaga, A., Pyron, R.A., Peñafiel, N., Romero-Barreto, P., Culebras, J., Bustamante, L., YánezMuños, M.H., Guayasamin, J.M. (2016) Comparative phylogeography reveals cryptic diversity and repeated patterns of cladogenesis for amphibians and reptiles in northwestern Ecuador. PLoS ONE, 11(4), e0151746. doi:10.1371/journal. pone.0151746

Beaupre, S.J., Jacobson, E.R., Lillywhite, H.B., Zamudio, K. (2004) Guidelines for use of live amphibians and reptiles in field and laboratory research. American Society of Ichthyologists and Herpetologists, Lawrence, $43 \mathrm{pp}$.

Castroviejo-Fisher, S., Guayasamin, J.M., Gonzalez-Voyer, A. \& Vilà, C. (2014) Neotropical diversification seen through glassfrogs. Journal of Biogeography, 41, 6680. http://dx.doi.org/10.1111/jbi.12208

Cisneros-Heredia, D.F. \& McDiarmid, R.W. (2007) Revision of the characters of Centrolenidae (Amphibia: Anura: Athesphatanura), with comments on its taxonomy and the description of new taxa of glassfrogs. Zootaxa, 1572, 1-82.

Cisneros-Heredia, D.F. \& Yánez-Muñoz, M.H. (2007) A new species of glassfrog (Centrolenidae) from the southern Andean foothills on the West Ecuadorian region. South American Journal of Herpetology, 2, 1-10.

de Queiroz, K. (2005) Ernst Mayr and the modern concept of species. Proceedings of the National Academy of Sciences USA, 102, 6600-6607.

de Queiroz, K. (2007) Species concepts and species delimitation. Systematic Biology, 56, 879886.

Delia, J., Bravo-Valencia, L., Warkentin, K.M. (2017) Patterns of parental care in Neotropical 
477

478

479

480

481

482

483

484

485

486

487

488

489

490

491

492

493

494

495

496

497

498

499

500

501

502

503

504

505

506

glassfrogs: fieldwork alters hypotheses of sex-role evolution. Journal of Evolutionary Biology, 30, 898-914

Delia, J., Rivera-Ordonez, J.M., Salazar-Nicholls, M.J., \& Warkentin, K.M. (2018) Hatching plasticity and the adaptive benefits of extended embryonic development in glassfrogs. Evolutionary Ecology, https://doi.org/10.1007/s10682-018-9963-2

Duellman, W.E. (1981) Three new species of centrolenid frogs from the Pacific versant of Ecuador and Colombia. Occasional Papers of the Museum of Natural History, University of Kansas, 88, 1-9.

Espinoza, S., Zapata Ríos, G., Saavedra, M.A., Alava, J.J., Tirira, D. Jaguar de la Costa (Panthera onca centralis). Pp 94-95, In: Libro Rojo de los mamíferos del Ecuador (D.G. Tirira, ed.), 2a. edición. Fundación Mamíferos y Conservación, Pontificia Universidad Católica del Ecuador, Ministerio del Ambiente del Ecuador. Publicación especial sobre los mamíferos del Ecuador 8. Quito.

Freile, J.F. \& Santander, T. (2005) Áreas Importantes para la Conservación de las Aves en Ecuador. Aves \& Conservación (Corporación Ornitológica del Ecuador), BirdLife International, Conservación Internacional y Ministerio del Ambiente de Ecuador. Quito, Ecuador.

Frost, D. (2018) Amphibian Species of the World: an Online Reference. Version 6.0. Electronic Available from: http://research.amnh.org/herpetology/amphibia/index.html. American Museum of Natural History, New York, USA. (Accessed: August 28, 2018).

Krabbe, N. (2008) Arid valleys as dispersal barriers to high-Andean forest birds in Ecuador. Cotinga, 29, 28-30.

Graves, G.R. (1988) Linearity of geographic range and its possible effect on the population structure of Andean birds. Auk, 105:47-52.

Guayasamin, J.M. (2013) A new yellow species of glassfrog (Centrolenidae: Nymphargus) from the Amazonian slopes of the Ecuadorian Andes. Zootaxa, 3651, 193-200.

Guayasamin, J.M. \& Bonaccorso, E. (2004) A new species of glass frog (Centrolenidae: Cochranella) from the lowlands of northwestern Ecuador, with comments on the Cochranella granulosa group. Herpetologica, 60, 485-494.

Guayasamin, J.M., Bustamante, M.R., Almeida-Reinoso, D. \& Funk, W.C. (2006) Glass frogs 
507

508

509

510

511

512

513

514

515

516

517

518

519

520

521

522

523

524

525

526

527

528

529

530

531

532

533

534

535

536

(Centrolenidae) of Yanayacu Biological Station, Ecuador, with the description of a new species and comments on centrolenid systematics. Zoological Journal of the Linnean Society, 147, 489-513.

Guayasamin, J.M., Castroviejo-Fisher, S., Ayarzagüena, J., Trueb, L. \& Vilà, C. (2008)

Phylogenetic relationships of glassfrogs (Centrolenidae) based on mitochondrial and nuclear genes. Molecular Phylogenetics and Evolution, 48, 574-595.

Guayasamin, J.M., Castroviejo-Fisher, S., Trueb, L., Ayarzaguena, J., Rada, M. \& Vilà, C. (2009) Phylogenetic systematics of glassfrogs (Amphibia: Centrolenidae) and their sister taxon Allophryne ruthveni. Zootaxa, 2100, 1-97.

Guayasamin, J.M., Bonaccorso, E., Duellman, W.E., Coloma, L.A. (2010) Genetic differentiation in the nearly extinct harlequin frogs (Bufonidae: Atelopus), with emphasis on the Andean Atelopus ignescens and A. bomolochos species complexes. Zootaxa, 2574, $55-68$.

Hoogmoed, M.S. (1985) A new genus of toads (Amphibia: Anura: Bufonidae) from the Pacific slopes of the Andes in northern Ecuador and southern Colombia, with descriptions of two new species. Zoologische Mededelingen, 59, 251-274.

Hutter, C.R. \& Guayasamin, J.M. (2012) A new cryptic species of glassfrog (Centrolenidae: Nymphargus) from Reserva Las Gralarias Ecuador. Zootaxa, 3257, 1-21.

Hutter, C.R. \& Guayasamin, J.M. (2015) Cryptic diversity concealed in the Andean cloud forests: two news species of rainfrogs (Pristimantis) uncovered by molecular and bioacustic data. Neotropical Biodiversity, 1, 36-59. http://dx.doi.org/10.1080/23766808.2015.1100376

Hutter, C.R., Guayasamin, J.M. \& Wiens, J.J. (2013) Explaining Andean megadiversity: the evolutionary and ecological causes of glassfrog elevational richness patterns. Ecology Letters,

$$
\text { 16, 1135-1144. http://dx.doi.org/10.1111/ele.12148 }
$$

Hutter, C.R., Escobar-Lasso, S., Rojas-Morales, J.A., Gutiérrez-Cárdenas, P.D.A., Imba, H., Guayasamin, J.M. (2013) The territoriality, vocalizations and aggressive interactions of the red-spotted glassfrog, Nymphargus grandisonae, Cochran and Goin, 1970 (Anura:

Centrolenidae). Journal of Natural History, 47, 3011-3032.

IUCN (2001) IUCN Red List Categories and Criteria: Version 3.1. IUCN Species Survival Commission. IUCN, Gland, Switzerland and Cambridge, UK. 
537 Katoh, K. \& Standley, D.M. (2013) MAFFT Multiple Sequence Alignment Software Version 7:

538 Improvements in Performance and Usability. Molecular Biology and Evolution, 30, 772-780.

539 Kalyaanamoorthy, S., Minh, B.Q., Wong, T.K.F., Haeseler, A., Jermiin, L.S. (2017)

540 ModelFinder: fast model selection for accurate phylogenetic estimaes. Nature Methods, 14,

541 587-589. https://doi.org/10.1038/nmeth.4285

542 Köhler, J., Jansen, M., Rodríguez, A., Kok, P.J.R., Toledo, L.F., Emmrich, M., Glaw, F.,

543 Haddad, C.F.B., Rödel, M., Vences, M. (2017) The use of bioacoustics in anuran

544 taxonomy: theory, terminology, methods and recommendations for best practice.

$545 \quad$ Zootaxa, 4251, 001-124.

546 Lessmann, J., Fajardo, J., Muñoz, J., Bonaccorso, E. (2016) Large expansion of oil industry in

547

548

549

550

551

552

553

554

555

556

557

558

559

560

561

562 the Ecuadorian Amazon: biodiversity vulnerability and conservation alternatives. Ecology \& Evolution, 6, 4997-5012.

Lynch, J.D., \& Duellman, W.E. (1973) A review of the centrolenid frogs of Ecuador, with descriptions of new species. Occasional Papers of the Museum of Natural History, University of Kansas, 16, 1-66.

Lynch, J.D., \& Duellman, W.E. (1997) Frogs of the genus Eleutherodactylus in western Ecuador. Systematics, ecology, and biogeography. Special Publication. Natural History Museum, University of Kansas, 23, 1-236.

Lynch, R.L., Kohn, S., Ayala-Varela, F., Hamilton, P.S., Ron, S. (2014) Rediscovery of Andinophryne olallai Hoogmoed, 1985 (Anura, Bufonidae), an enigmatic and endangered Andean toad. Amphibian \& Reptilian Conservation, 8, 1-7.

Mittermeier, R.A., Ratsimbazafy, J., Rylands, A.B., Williamson, L., Oates, J.F., Mbora, D., Ganzhorn, J.U., Rodríguez-Luna, E., Palacios, E., Heymann, E.W., Kierulff, M.C.M., Yongcheng, L., Supriatna, K., Roos, C., Walker, S., Aguiar, J.M. (2007) Primates in Peril: The World's 25 Most Endangered Primates, 2006-2008. Primate Conservation, 22, 1-40.

Maddison, W.P. \& Maddison, D.R. (2010) Mesquite: a modular system for evolutionary 564 analysis. Version 2.74. Available at: http://mesquiteproject.org.

565

Minh, B.Q., Nguyen, M.A.T., Haeseler, A. (2013). Ultrafast approximation for phylogenetic bootstrap. Molecular Biology and Evolution, 30, 1188-1195. https://doi.org/10.1093/molbev/mst024 
568 Nguyen, L.T., Schmidt, H.A., Haeseler, A., Minh, B.Q. (2015) IQ-TREE: a fast and effective

569

570

571

572

573

574

575

576

577

578

579

580

581

582

583

584

585

586

587

588

589

590

591

592

593

594

595

596

597

598 stochastic algorithm for estimating maximum-likelihood phylogenies. Molecular Biology and Evolution, 32, 268-274. doi: 10.1093/molbev/msu300

Prieto-Torres, D.A., Cuervo, A.M., Bonaccorso, E. (2018) On geographic barriers and Pleistocene glaciations: Tracing the diversification of the Russet-crowned Warbler (Myiothlypis coronata) along the Andes. PLoS ONE, 13(3): e0191598. https://doi.org/10.1371/journal. pone.0191598

Rada, M., Ospina-Sarria, J.J., Guayasamin, J.M. (2017) A taxonomic review of tan-brown Glassfrogs (Anura: Centrolenidae), with the description of a new species from southwestern Colombia. South American Journal of Herpetology, 12, 136-156.

Remsen, J.V. Jr. (1984) High incidence of "leapfrog" pattern of geographic variation in Andean birds: implications for the speciation process. Science, 224, 171-173.

Roy, B., Zorrilla, M., Endara, L., Thomas, D., Vandegrift, R., Rubenstein, J.M., Policha, T., \& Rios-Touma, B. (2018) New mining concessions will severely decrease biodiversity and ecosystem services in Ecuador. Tropical Conservation Science, 11: 1-20. DOI:10.1177/1940082918780427

Ruiz-Carranza, P.M. \& Lynch, J.D. (1991) Ranas Centrolenidae de Colombia I. Propuesta de una nueva clasificación genérica. Lozania, 57, 1-30.

Ruiz-Carranza, P.M. \& Lynch, J.D. (1995) Ranas Centrolenidae de Colombia V. Cuatro nuevas especies de Cochranella de la Cordillera Central. Lozania, 62, 1-24.

Ruiz-Carranza, P.M. \& Lynch, J.D. (1997) Ranas Centrolenidae de Colombia X. Los centrolénidos de un perfil del flanco oriental de la Cordillera Central en el Departamento de Caldas. Revista de la Academia Colombiana de Ciencias Exactas, Físicas y Naturales, 21, 541-553.

Savage, J.M., \& Heyer, W.R. (1967) Variation and distribution in the tree-frog genus Phyllomedusa. Beiträge zur Neotropischen Fauna, V (2), 111-131.

Schwitzer, C., Mittermeier, R.A., Rylands, A.B., Chiozza, F., Williamson, E.A., Macfie, E.J., Wallis, J., Cotton, A. (eds.). 2017. Primates in Peril: The World's 25 Most Endangered Primates 2016-2018. IUCN SSC Primate Specialist Group (PSG), International Primatological Society (IPS), Conservation International (CI), and Bristol Zoological Society, Arlington, VA. 99 pp. 
599 Twomey, E., Delia, J., Castroviejo-Fisher, S. (2014) A review of northern Peruvian glassfrogs 600 (Centrolenidae), with the description of four new remarkable species. Zootaxa, 3851: 1$601 \quad 87$

602 Wild, E.R. (1994) Two new species of centrolenid frogs from the Amazonian slope of the 603 Cordillera Oriental, Ecuador. Journal of Herpetology, 28, 299-310.

604 
605 Appendix I: Examined specimens.

606 Nymphargus buenaventura: Ecuador: Provincia de El Oro: Cantón El Guabo: Cascadas de

607

608

609

610

611

612

613

614

615

616

617

618

619

620

621

622

623

624

625

626

Manuel, 800 m, DHMECN 10982; Cantón Piñas: Reserva Buenaventura (0338’S, 7945’W, 1200 m), DHMECN 3563 (holotype), 2524, 3561-62 (paratypes).

Nymphargus balionotus: Ecuador: Provincia de Imbabura: Río Manduriacu Reserve $\left(0.31^{\circ} \mathrm{N}\right.$, $\left.78.85^{\circ} \mathrm{W} ; 1215-1238 \mathrm{~m}\right)$, ZSFQ 0531-533.

Nymphargus griffithsi: Ecuador: Provincia de Pichincha: Río Saloya, 1219 meters, BMNH 1940.2.20.4 (holotype), BMNH 1940.2.20.3 (paratype); Reserva Las Gralarias, MZUTI 100, 102 and 099, “Hercules Giant Tree Frog Creek”, (001.529’ S, 7842.243’ W; 2175 m); MZUTI 101, “Five Frog Creek”, (001.870’ S, 7842.358’ W; 2150 m); MZUTI 098, “Heloderma Creek” (001.245’ S, 7842.370’ W; 2200 m).

Nymphargus ignotus: Colombia: Departamento del Valle del Cauca: Municipio de La Cumbre, Corregimiento de Bitaco, Vereda Chicoral, tributary of Río Bitaco $\left(03^{\circ} 34^{\prime} 09.9^{\prime \prime} \mathrm{N}\right.$, 76³5'42.7'W, 1950 m), ICN 55799-800, ICN 21524-5; Peñas Blancas, Farallones de Cali, ca. $6 \mathrm{~km}$ by road SW of Pichindé $\left(04^{\circ} 53^{\prime} 05.2^{\prime \prime} \mathrm{N}, 76^{\circ} 08^{\prime} 52.5^{\prime \prime} \mathrm{W}, 1900 \mathrm{~m}\right), \mathrm{ICN}$ 14748, holotype, ICN 14749-77; Municipio de Dagua, Finca San Pedro, headwater of the Quebrada La Seca, $8 \mathrm{~km} \mathrm{~S}$ of Queremal $\left(03^{\circ} 28^{\prime} 30,1^{\prime \prime} \mathrm{N}, 76^{\circ} 42^{\prime} 10.8^{\prime \prime} \mathrm{W}, 1940-2050 \mathrm{~m}\right)$, ICN 41333-41. Departamento de Chocó: Municipio de San José del Palmar, 12-12.6 km on the San José del Palmar-Cartago road $\left(03^{\circ} 24^{\prime} 59.8^{\prime \prime} \mathrm{N}, 76^{\circ} 37^{\prime} 12.6^{\prime \prime} \mathrm{W}, 1850 \mathrm{~m}\right)$, ICN 19641. Departamento de Risaralda: Municipio de Mistrató, km 10-11 carretera MistratóSan Antonio del Chami, quebrada Mampay $\left(05^{\circ} 21^{\prime} \mathrm{N}, 75^{\circ} 52^{\prime} \mathrm{W}, 1760 \mathrm{~m}\right)$, ICN 30040-8, ICN 30056. 
627 Nymphargus lasgralarias: Ecuador: Provincia de Pichincha: Reserva Las Gralarias, MZUTI 096 628 (holotype), MZUTI 091-095, 097 (paratypes).

629 Nymphargus luminosus: Colombia: Departamento de Antioquia: Municipio de Frontino:

630 Corregimiento Nutibara: Km 23-27 on the Nutibara-La Blanquita road, 1000-1430 m, 631 ICN 15930 (holotype), ICN 15918-20, 15922-29, 15931-33 (paratypes).

632 Nymphargus spilotus: Colombia: Departamento de Caldas: Municipio de Samaná, 633 Corregimiento Florencia: sitio "Rancho Quemado", 1940 m, ICN 35155 (holotype); sitio 634 El Estadero, 1850 m, ICN 35157-58 (paratypes); zona "El Estadero" (o "Rancho 635 Quemado”), ICN 38073 (paratype).

636

637 


\section{Table $\mathbf{1}$ (on next page)}

Differences between N. manduriacu sp. nov. and similar species from the Pacific Andes of Ecuador and Pacific and Central Andes of Colombia. 


\begin{tabular}{|c|c|c|c|c|c|}
\hline & $\begin{array}{c}\text { N. } \\
\text { manduriacu } \\
\text { sp. nov. }\end{array}$ & $\begin{array}{c}N . \\
\text { buenaventura }\end{array}$ & N. ignotus & N. luminosus & N. spilotus \\
\hline $\begin{array}{l}\text { Distribution } \\
\text { (elevation) }\end{array}$ & $1215-1238 \mathrm{~m}$ & $800-1200 \mathrm{~m}$ & $1280-2050 \mathrm{~m}$ & $1140-1430 \mathrm{~m}$ & $1850-1940 \mathrm{~m}$ \\
\hline $\begin{array}{l}\text { SVL (adult } \\
\text { males) }\end{array}$ & $\begin{array}{c}24.0-25.7 \\
(n=3)\end{array}$ & $\begin{array}{c}20.9-22.4 \\
(n=4)\end{array}$ & $\begin{array}{c}22.2-25.4 \\
(n=61)\end{array}$ & $\begin{array}{c}27.7-30.0 \\
(n=15)\end{array}$ & $\begin{array}{c}25.7-26.6 \\
(n=2)\end{array}$ \\
\hline $\begin{array}{l}\text { Dorsal coloration } \\
\text { in life }\end{array}$ & $\begin{array}{l}\text { Grayish green } \\
\text { with yellow } \\
\text { spots, which } \\
\text { are sometimes } \\
\text { surrounded by } \\
\text { ill-defined } \\
\text { rings }\end{array}$ & $\begin{array}{l}\text { Light green } \\
\text { with diffuse } \\
\text { pale yellow } \\
\text { spots }\end{array}$ & $\begin{array}{c}\text { Dorsum pale tan to } \\
\text { olive brown with } \\
\text { black ocelli } \\
\text { surrounding orange or } \\
\text { yellow spots }\end{array}$ & $\begin{array}{c}\text { Green with } \\
\text { numerous } \\
\text { yellow spots } \\
(95-217 \text { spots; } n \\
=16)\end{array}$ & $\begin{array}{l}\text { Olive green with } \\
\text { small yellow spots }\end{array}$ \\
\hline $\begin{array}{l}\text { Webbing } \\
\text { between Fingers } \\
\text { III and IV }\end{array}$ & $\begin{array}{l}\text { Basal (Fig. } \\
6 \mathrm{~A})\end{array}$ & Basal & Basal & $\begin{array}{l}\text { Basal, but more } \\
\text { extended than in } \\
\text { other } \\
\text { Nymphargus } \\
\text { (Fig. 6B) }\end{array}$ & Basal (Fig. 6D) \\
\hline Source & This study & $\begin{array}{l}\text { Cisneros-Heredia } \\
\text { \& Yánez-Muñoz } \\
\text { (2007); this study }\end{array}$ & Rada et al. (2017) & $\begin{array}{l}\text { Ruiz-Carranza \& } \\
\text { Lynch (1995); this } \\
\text { study }\end{array}$ & $\begin{array}{c}\text { Ruiz-Carranza \& } \\
\text { Lynch (1997); this } \\
\text { study }\end{array}$ \\
\hline
\end{tabular}




\section{Table 2 (on next page)}

Morphological measurements (in $\mathrm{mm}$ ) of the type series of $N$. manduriacu sp. nov. 


\begin{tabular}{|l|c|c|c|c|}
\hline & ZSFQ-0466 & ZSFQ-0463 & ZSFQ-0465 & ZSFQ-0462 \\
\hline male & male & male & female \\
\hline SVL & 25.3 & 25.7 & 24.0 & 28.8 \\
\hline Tibia length & 15.0 & 15.0 & 14.2 & 18.0 \\
\hline Foot length & 12.1 & 11.6 & 11.0 & 13.8 \\
\hline Head length & 8.2 & 8.3 & 8.1 & 8.7 \\
\hline Head width & 9.1 & 8.8 & 8.7 & 10.2 \\
\hline Snout to eye distance & 2.8 & 2.8 & 3.2 & 3.7 \\
\hline Interorbital distance & 3.7 & 3.9 & 3.9 & 4.0 \\
\hline Upper eyelid width & 2.2. & 2.1 & 2.2 & 2.6 \\
\hline Internarinal distance & 2.3 & 2.4 & 2.1 & 2.4 \\
\hline Eye diameter & 3.4 & 3.2 & 3.1 & 3.8 \\
\hline Tympanum diameter & 0.8 & 0.9 & 1.0 & 1.2 \\
\hline Radioulna length & 5.7 & 5.6 & 5.5 & 6.9 \\
\hline Hand & 8.9 & 9.1 & 8.5 & 10.0 \\
\hline Finger I & 4.1 & 4.4 & 4.2 & 5.4 \\
\hline Finger II & 5.5 & 5.2 & 4.8 & 6.1 \\
\hline Disc of Finger III width & 1.8 & 1.9 & 1.7 & 1.8 \\
\hline
\end{tabular}


Figure 1

Map of Ecuador showing the location of Río Manduriacu Reserve, the type locality of Nymphargus manduriacu sp. nov. 


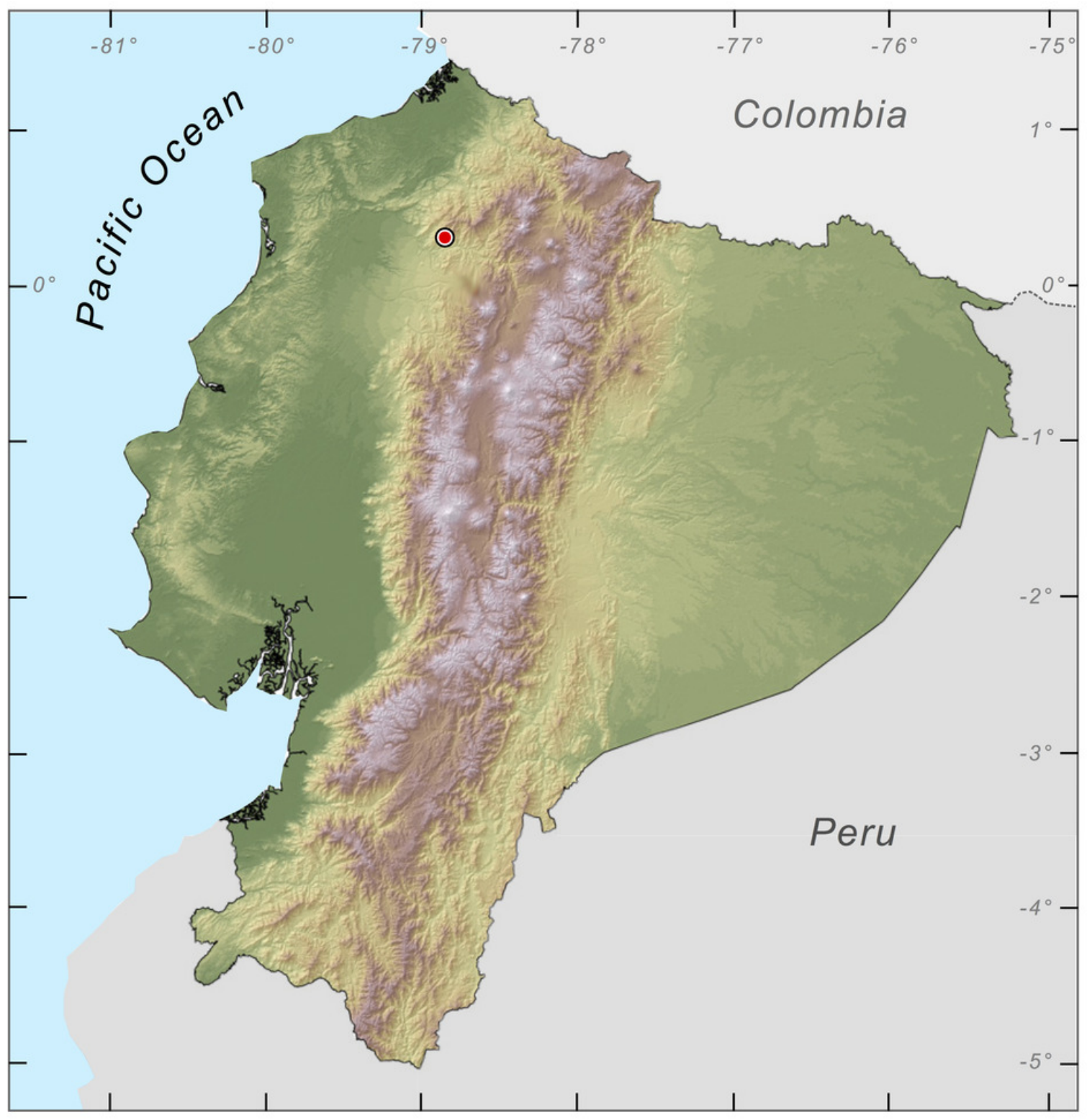


Figure 2

Inferred mitochondrial phylogeny of the genus Nymphargus, with the positioning of the new species, Nymphargus manduriacu sp. nov.

Clade support values (bootstraps) were obtained as described in Minh et al. (2013). Taxa in blue correspond to sequences added in this study. 


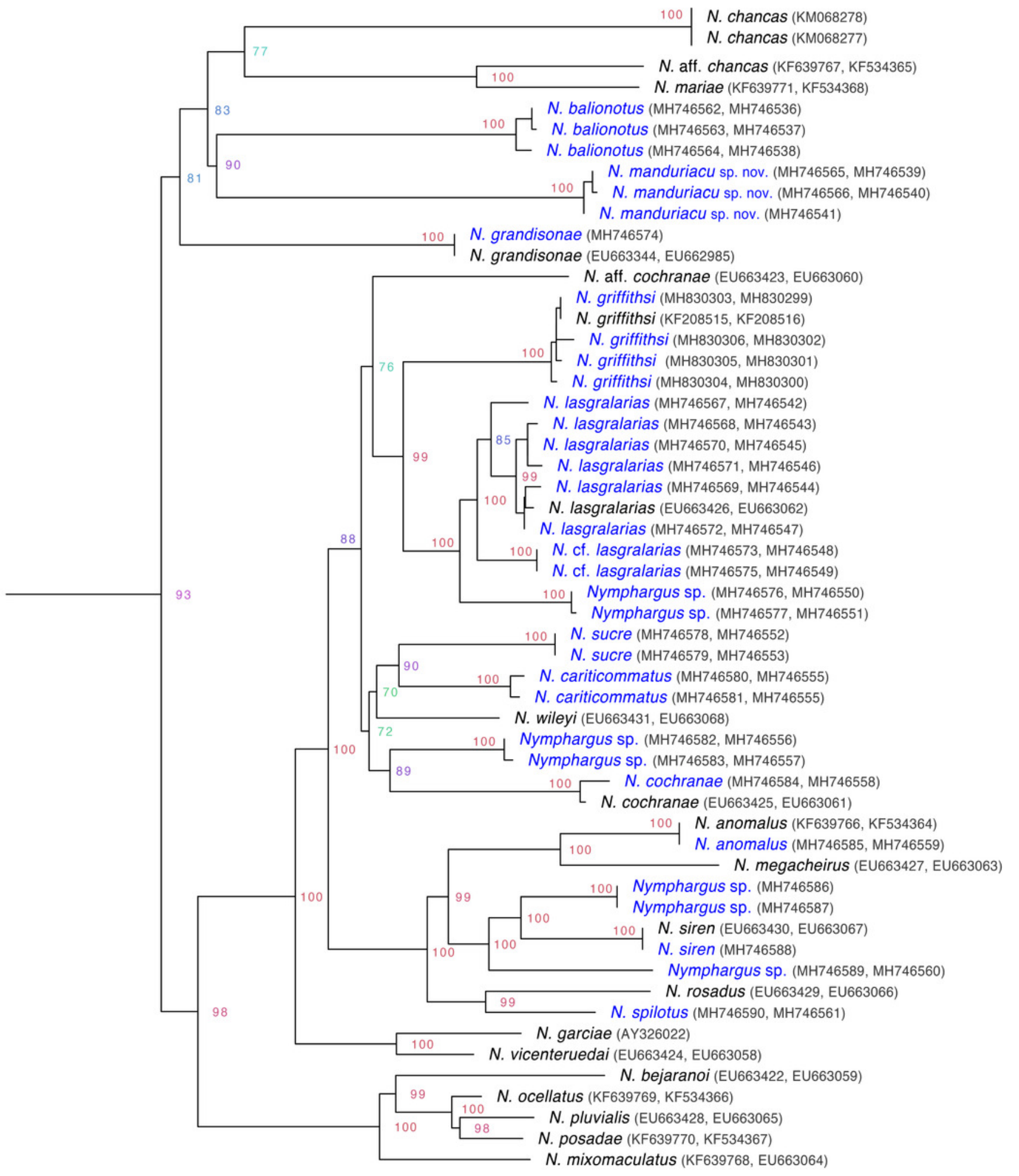


Figure 3

Nymphargus manduriacu sp. nov. in life.

(A-C) Adult male, holotype, ZSFQ 0466. (D-F) Adult female, paratype, ZSFQ 0462.
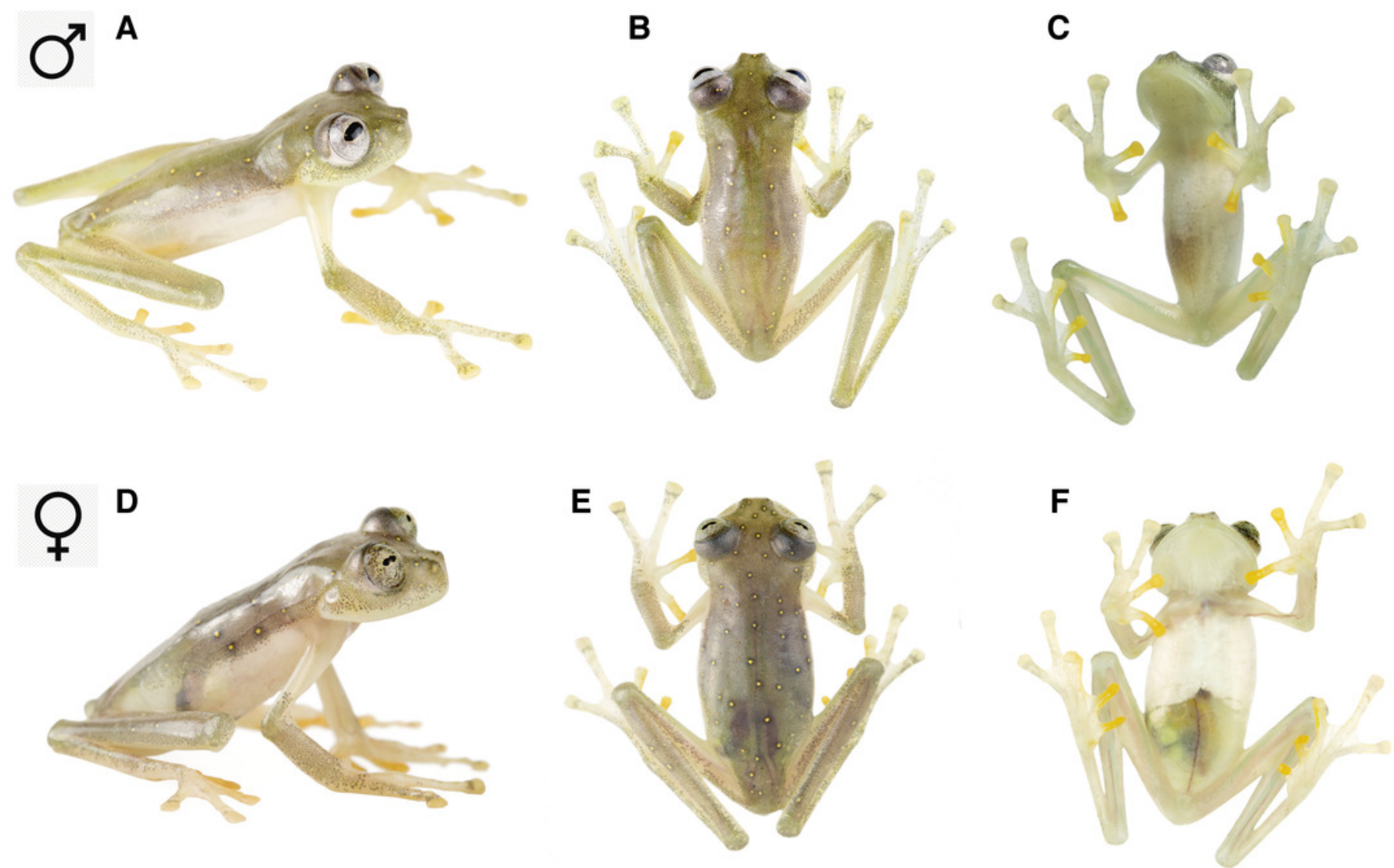
Figure 4

Life stages of Nymphargus manduriacu sp. nov.

(A) Egg clutch (ZSFQ 467). (B) Metamorph (ZSFQ 618). 

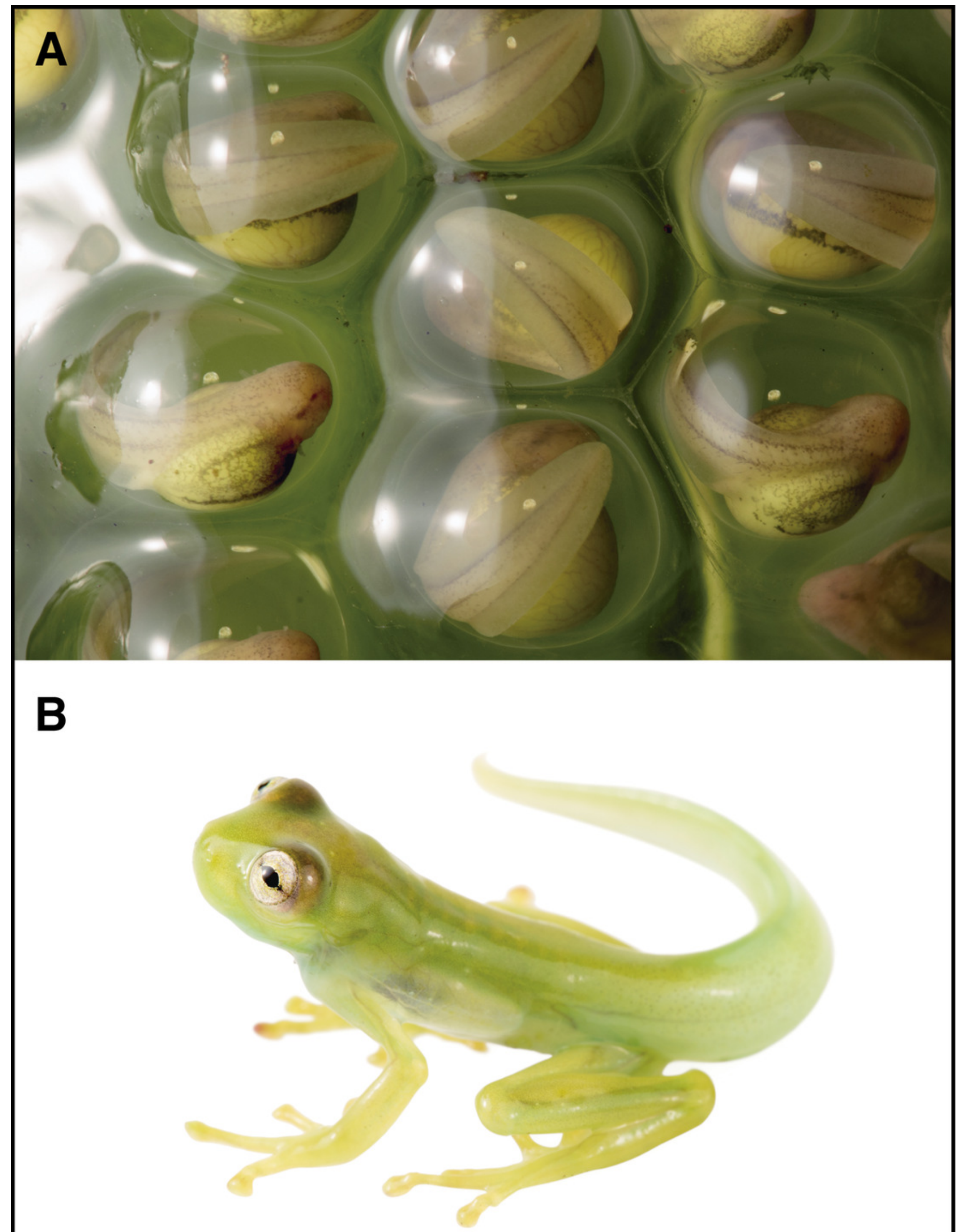


\section{Figure 5}

Nymphargus manduriacu sp. nov. and similar species.

(A) N. manduriacu, Reserva Río Manduriacu, Ecuador, uncollected. (B) N. buenaventura, Cascadas de Manuel, Cantón El Guabo, Provincia El Oro, 800 m, Ecuador, DHMECN 10982, photo by Juan Carlos Sánchez. (C) N. luminosus, Quebrada la Honda y La Amarill, Verada Venados Arriba, Municipio de Frontino, Departamento de Antioquia, Colombia, MAR 3576, photo by Marco Rada. (D) N. spilotus, Parque Nacional Natural Selva de Florencia, Colombia, JD 060, photo by Jesse Delia.

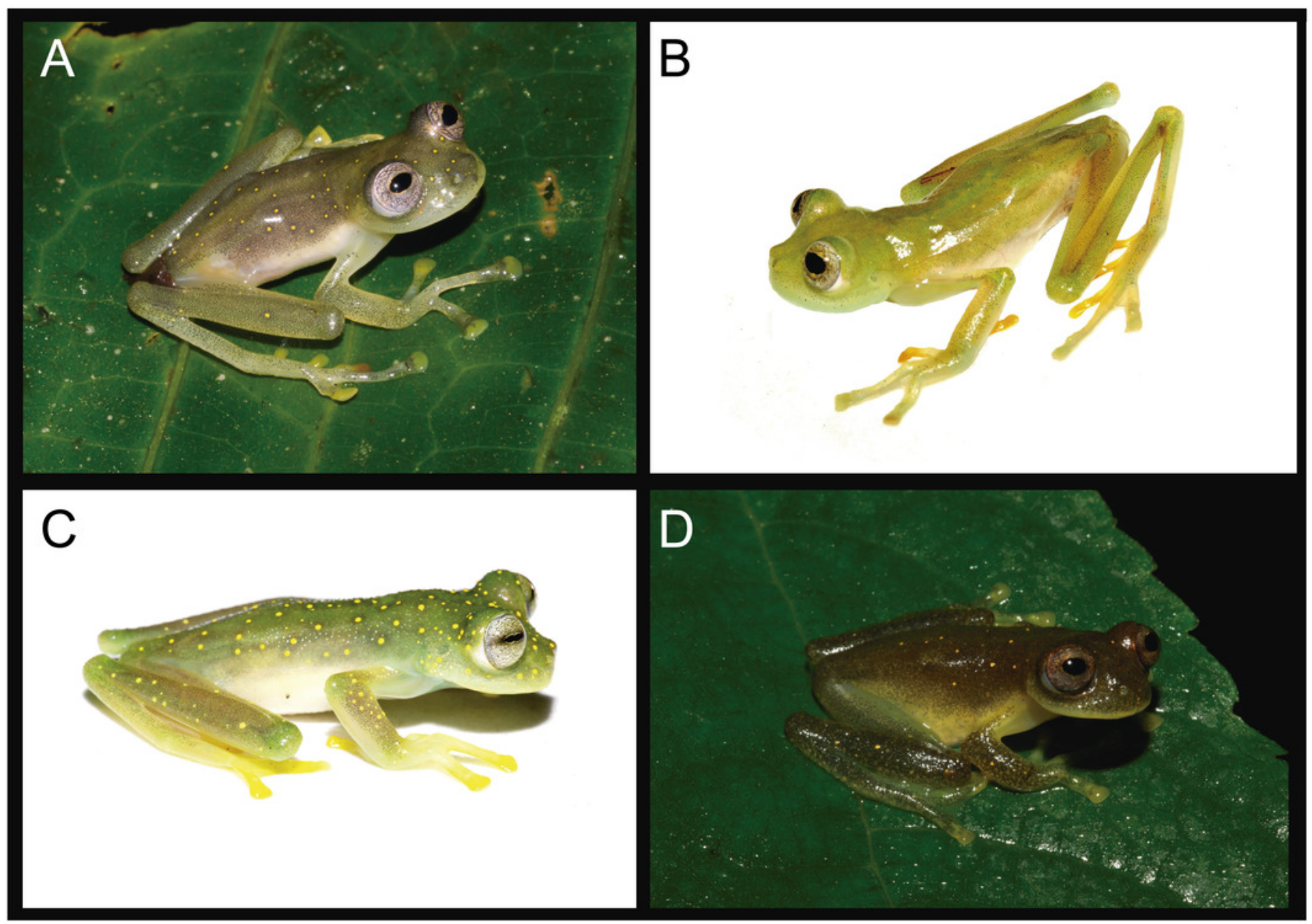


Figure 6

Hand webbing Nymphargus manduriacu sp. nov. and similar species.

(A) N. manduriacu, ZSFQ 0463, adult male, paratype. (B) N. luminosus, ICN 15930, adult female, holotype. (C) N. spilotus, ICN 35255, adult female, holotype.
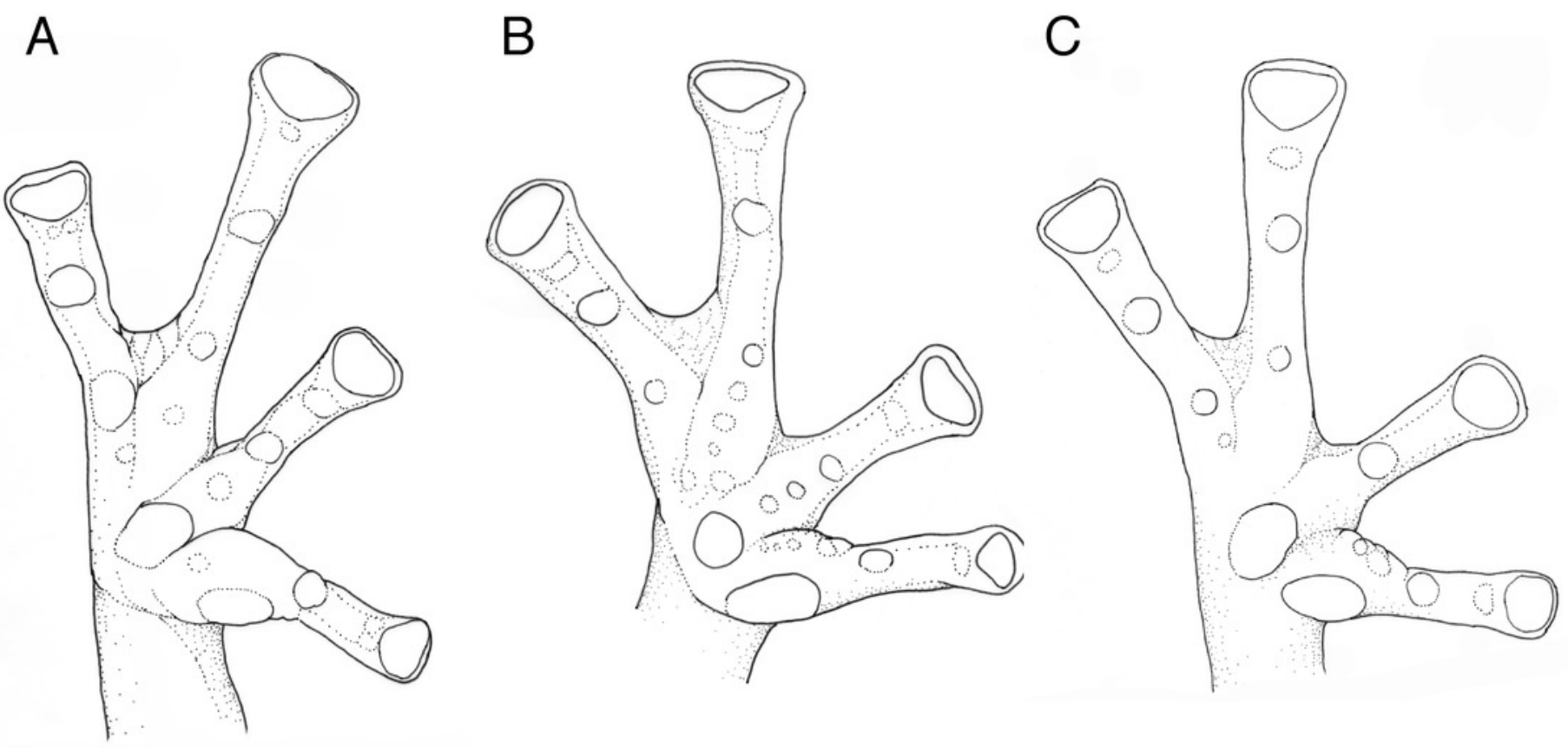


\section{Figure 7}

Call of the holotype of Nymphargus manduriacu sp. nov.

(A) Oscillogram. (B) Audiospectrogram. File number: LBE-C-042.

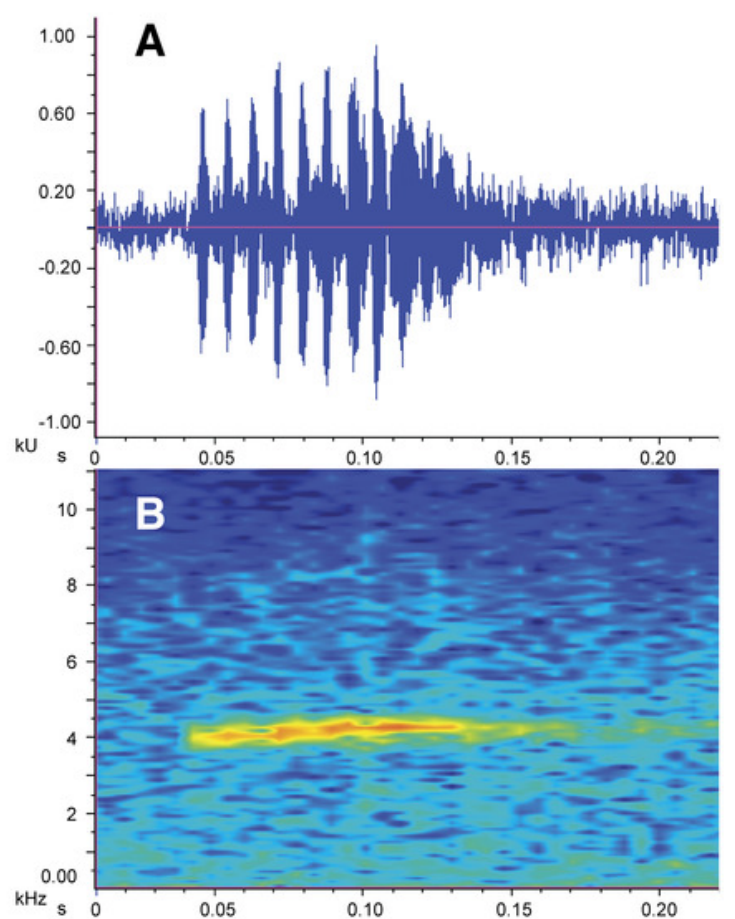




\section{Figure 8}

Map of Río Manduriacu Reserve (Imbabura province, Ecuador), with conservation plans and mining threats.

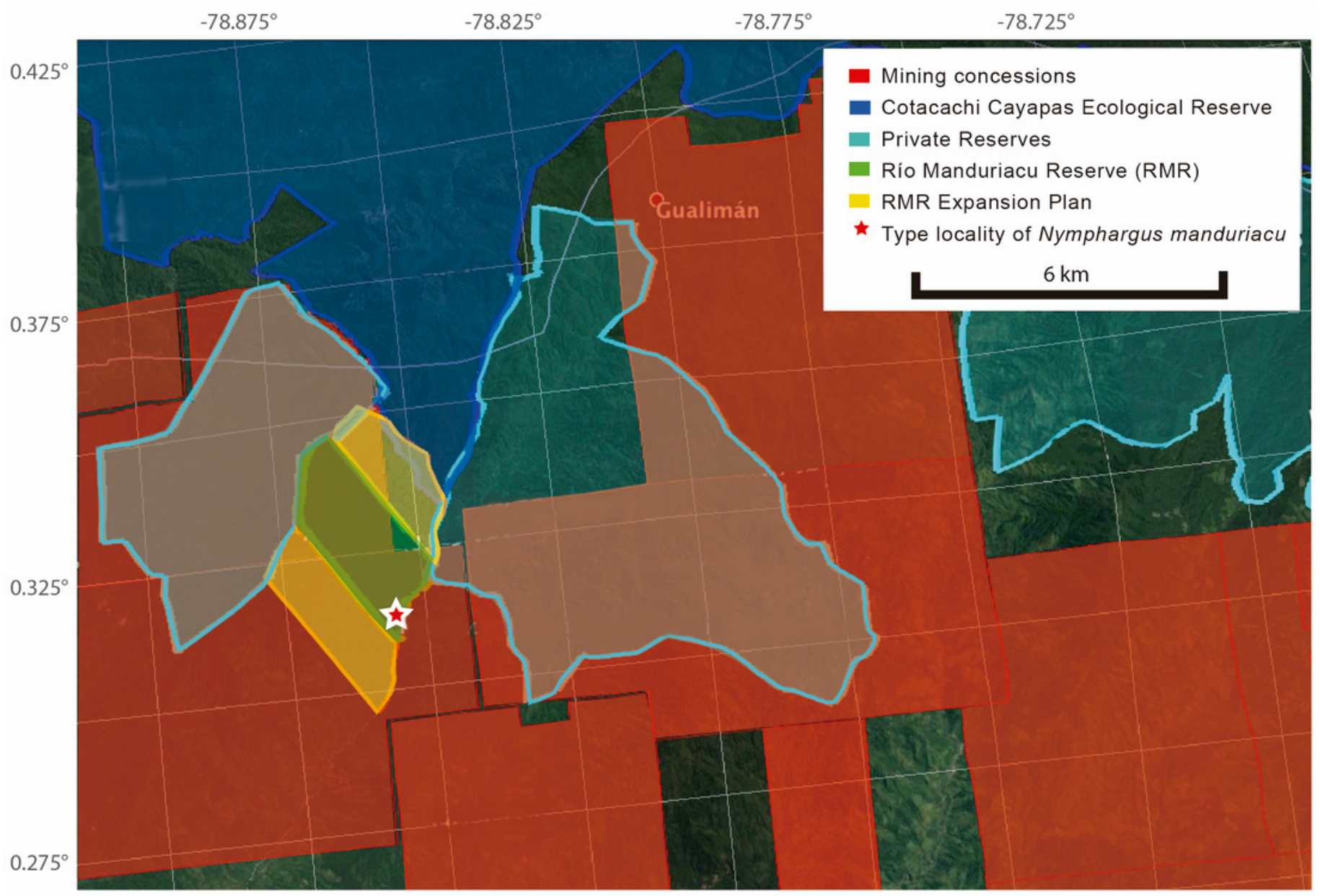

